OmniAkuatika, 12 (2): 11-16, 2016
ISSN: 1858-3873 print / 2476-9347 online
Research Article

\title{
The Influence of Ketapang (Terminalia catappa) Bark Extract on Survival Rate and Histopathology of Common Carp (Cyprinus carpio) Liver Which is Infected by Aeromonas hydrophilia
}

\author{
Maftuch, Gede Angga Krishna Fariestha, Heny Suprastyani \\ Dept. Aquaculture, Faculty of Fisheries and Marine Science, Brawijaya University. Veteran Street, Malang, East \\ Java Indonesia 65145, \\ *Corresponding author : maftuch@ub.ac.id
}

Received 30 May 2016; Accepted 15 October 2016; Available online 29 November 2016

\begin{abstract}
This research aims to investigate the influence of Ketapang (Terminalia catappa) bark extract (KBE) on the survival rate and liver histopathology of Common carp (Cyprinus carpio) which was Infected by Aeromonas hydrophilia. Experimental design with Completely Randomized Design (CRD). Obtained data were analyzed by using Analysis of Varian (ANOVA) and further Least Significant Differed (LSD) analysis. The main parameters in this research are the damage level of Common carp liver based on scoring value and survival rates. Based on the result from scoring data, it was shown that there is altered-histology on Common carp fish liver. The damages found were congestion, melanomacrofag, and necrosis. In average, treatment A (730 ppm) had the highest damage average while treatment $C$ (770 ppm) had the lowest damage average value. The final result shows that the bigger the dose, the lower the damage. In contrast, the survival rates would decrease with the higher dose of KBE. It can be concluded that KBE able to reduce the liver alteration however in some extend it will cause the mortality.
\end{abstract}

Keywords : common carp, histopathology, ketapang, liver, survival rate.

\section{Introduction}

Common carp is fresh water fish with high preferable because of its flavourous flesh. Therefore this fish is popular and favorite fish for Indonesian. However, the problem that often become the obstacle of fish cultivation is the emerging of diseases. These diseases can cause financial loss, and fail in their culture. Basically, disease will not directly attack on fish. It is through a related process on three factors, namely environment (water condition), host (fish), and the existence of pathogen (disease) organism. Thus, the appearance of diseases are the result of mismatched interaction between environment, fish, and disease organism (Kordi, 2004).

Antibacterial compound, oxytetracycline, sulfonamide and sulfamerazine have been used in many fish farming/cultivation and considered as the most effective solution in preventing diseases-caused bacteria such as A. hydrophila (Sumino et al. (2013). The use of antibiotics to overcome diseases resulted in a good result, however using antibiotics in a long period will cause side effects which are the increasing number of resistances bacteria and contamination to the environment. Furthermore, the use of antibiotics in a big scale cultivation is less effective because of the price of antibiotics. Therefore, an alternative for antibiotics usage is still in the priority effort to overcome the fish disease caused by bacteria.

Ketapang tree is known as one of natural antibacteria ingridients. According to Wahjuningrum et al. (2008), Ketapang leaves has known as a useful solution for maintaining the water quality. Ketapang tree skin, fruit, and leaves are used as a traditional cure for various diseases such as skin diseases, dysentery, headache and stomach ache on childrens. Therefore, this three is a promising alternative natural ingridients that can be used to prevent and to cure bacteria attack.

The objectives of this research was to investigate Ketapang (Terminalia catappa) bark extract (KBE) on liver histopathology and survival rates of Common carp (Cyprinus carpio) which were infected by Aeromonas hydrophila. 


\section{Materials and methods}

\section{Materials}

Common carp (Cyprinus carpio) fish from local fish-farmer in Batu City area, Ketapang (Terminalia catappa) tree skin, Aeromonas hydrophila Bacterium, NA (Nutrien Agar), NB (Nutrien Broth), Label Paper, Methanol, Alumunium Foil, Sample of Common carp liver, Haematoxylin Eosin, Paraffin, Filter Paper, distilled water/Aquadest, Alkohol $70 \%$, Cotton, Tissue Paper, Ethanol 96\%, Formalin $10 \%$. Aquarium with $40 \times 40 \times 40 \mathrm{~cm}^{3}$, Digital scales, autoclave, incubator, Aerator, Aeration hoses, Stone Aeration, Air Hose, Tray, Pipette drops, Hand Tally Counter, microscopes, microtomes, fish drain, Heater aquarium, DO meter, $\mathrm{pH}$ meter, Sectio sets, Bottle films.

\section{Methods}

\section{Fish preparation and common carp fish (Cyprinus carpio) infection}

Infection was done by using $A$. hydrophila bacteria with $10^{7} \mathrm{cel} / \mathrm{ml}$ density. The used dilution followed below formula:

$$
\begin{aligned}
V_{1} \times N_{1} & =V_{2} \times N_{2} \\
V_{1} \times 10^{9} & =20.000 \times 10^{7} \\
V_{1} & =\frac{20.000 \times 10^{7}}{10^{9}} \\
& =200 \mathrm{ml}
\end{aligned}
$$

The Common carp liver sample are taken before soaking process and observed from the colours, structures, and forms. 15 Common carp fish are soaked in each aquarium, then continuing the soaking process with the bacterium.

\section{Ketapang bark extract (KBE)}

$\mathrm{KBE}$ is added in accordance with the dose of $730 \mathrm{ppm}, 750 \mathrm{ppm}$ and $770 \mathrm{ppm}$. Treatments were done in 6 minutes until the first anxiousness symptoms of the fish. After that, fish were moved into another Aquarium, each contains 15 fish, then maintained until 10 days. Observation during fish maintaining period is using the below formula:

$$
S R=\frac{N t}{N o} \times 100 \%
$$

SR : Survival Rates on testing animals (\%)

$\mathrm{Nt}$ : Number of testing fish in the end of research.

No : Number of testing fish in the beginning of research.

\section{Liver tissue preparation}

The liver is taken in the end of the research in order to observe its hispathology. Liver samples were put on glass jar containing $10 \%$ formalin, then continued with the preparat making for histopathology investigation.

\section{Histopathology analysis}

Making hitopathology preparat was conducted with steps, namely:

- Fixation, the tissue was fixed inside buffer solution, formalin (10\%) for 24 hours.

- Dehidration, water withdrawn gradually with $70 \%, 80 \%, 90 \%$, 96\% and absolute alcohol for 2 hours.

- Clearing, alcohol from tissue was rinse by immersing the tissue into 1 solution xylol for an hour, xylol 2 for 2 hours and xylol 3 for 3 hours.

- Impregnation, immersing the ingridients into liquid paraffin at $56^{\circ} \mathrm{C}-60^{\circ} \mathrm{C}$ for several hours, then continued with re-immersing the ingridients in the same temperature liquid paraffin for the same period as the previous step.

- Embedding step, aims to simplify cutting process by using microtomes. During cutting process, the marked ingridients are considered already finishing the process previously. Next step is putting the cutting result into $40^{\circ} \mathrm{C}$ waterbath.

- Tissue colouring technique using HE:

a) Deparaffinized: tissue cutting result was put into xylol 1 for 5 minutes, xylol 2 for 5 minutes and xylol 3 for 5 minutes.

b) Hydration, the result tissue is put into absolute alcohol for 4 minutes, 96\% and $90 \%$ alcohol for 3 minute, $80 \%$ and $70 \%$ alcohol for 2 minutes and put under flowing water for 10 minutes

c) main colouring, by adding haematoxsilin colouring for 5 minutes and $1 \%$ eosin for 3-5 minutes.

d) Dehydration, the cutting result is put into $70 \%$ and $80 \%$ alcohol for 2 menit, $90 \%$ alcohol for 3 minutes, 96\% alcohol for 4 minutes and absolute alcohol for 5 minutes.

e) Clearing, was done by inserting the piece of tissue into xylol 1, xylol 2, dan xylol 3 for 5 minutes.

- Mounting, the preparates were glued using $D P X$ mounting medium, then covered with glass cover to prevent bubbles existence. Preparates were set aside in room temperature until the glue was drying, then observed in microscopes. 


\section{Data analysis}

The obtained data were statistically analysed using Analysisi of Varians (ANOVA) test with Completely Randomized Design (CRD). This was to investigate the influece of treatments with $F$ test as a value. If the $F$ test value is significantly different or highly different then there will be continued with lowest Least significant different (LSD) test to determine the differences between two treatments. Statistic analysis by giving scoring with semiquantitative and quantitative methods are use to investigate the damage level on liver tissue.

Semiquintative method was used to count the number of coloured area manually. The reading starts from left (according to preparat point position) to right then come down and shifted back to the edge (zig zag).

Semiquantitative method was seen from three point of views therefore can get maximum result towards damage level on liver tissue cells. Each point of view is observed its damaged cells level with congestion, melanomakrofag, and necrosis criteria. The damage percentage on each point of view was counted from the amount of damaged cells with the formula as below:

Damage Percentage $=$ The amount of damaged cells $\times 100 \%$ The amount of analysed cells

Then the obtained percentages are scores using number 1 to 4 . Number 1 showed level damaged tissue percentage of $0-5 \%$, number 2 showed level damaged tissue percentage of $6-25 \%$, number 3 is damaged tissue percentage level $26-50 \%$ and number 4 was level damaged tissue percentage of $>50 \%$.

\section{Result and discussion}

\section{Liver histopathology}

Common carp liver histopathological observation is done towards damage as resulted from congestion, melanomakrofag and necrosis by analysing the illustration from fish liver histopathology through preparation and observed from microscopes.

\section{Common carp liver histopathology (Cyprinus carpio)}

Normal control treatment medicine control, show the whole remaining tissue and neatly condition cells (Figure 1.B). A.hydrophila infection can be seen on the cells of Common carp (C. carpio). Liver tissue began to scattered and some damages were found such as congestion, which is blood clotting appeared in sinusioid glands and small blood vessel on liver, melanomacrofag which is melanin pigmen hoarding on liver cells and causes damage on it, and necrosis, cells death or bleeding caused by bacteria infection (Figure 1.C).

A.hydrophila has been connected with several diseases that are responsible to fish sickness, including decaying fin and tail, and haemorrahagic septicaemia. Haemorrahagic septicaemia is marked with the appearances of small wound on skin that often lead to fish scales exfoliation, bleeding on gill and rectal, ulcers, abscess, exophthalmia (swelling eye), and swollen stomach. In the internal organs, there is a possibility of ascitic liquid existence inside peritoneal cavity, anemia, also swelling and damages on kidney and liver.

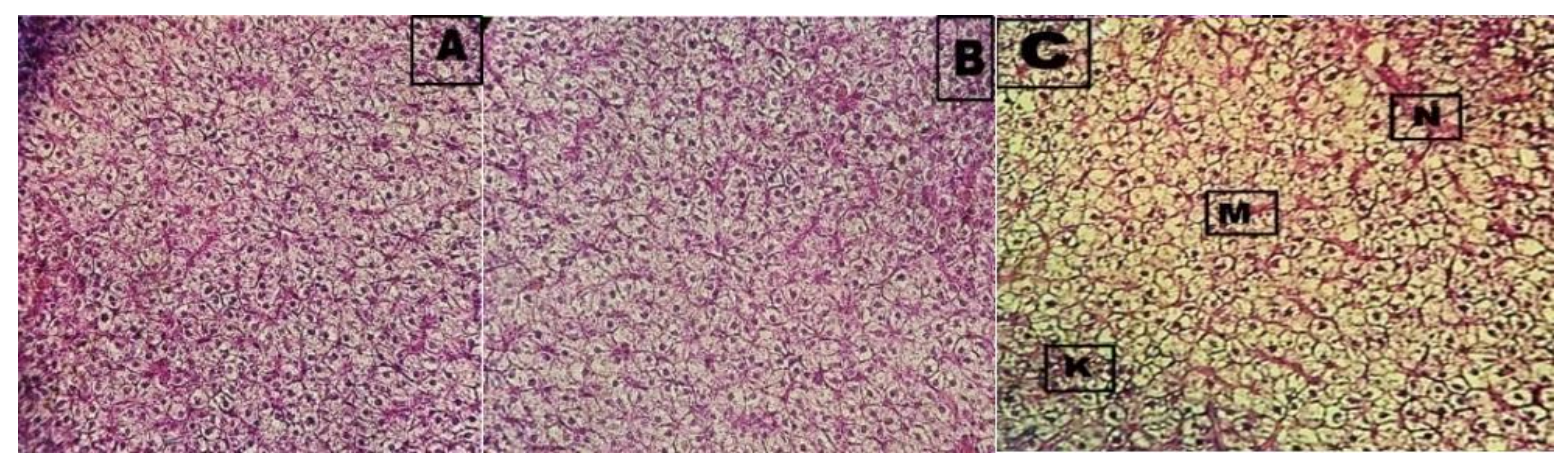

Figure 1. Liver tissue of Common carp fish. (A) Normal liver tissue with no treatment. (B) Liver tissue given with extract. (C) Liver tissue with $A$. hydrophila, (K) Congestion; (M) Melanomacrofag; (N) Necrosis. Observation is conducted using Binocular Microscope, 400x zoom. 


\section{Congestion}

The treatment gave a different average result towards the damages caused by congestion that appeared on Common carp (C.carpio) liver tissue. According to Tabbu (2000), congestion or hyperemia has the same definition namely the increasing blood volume on tissue. Congestion happens because blood is excessively accumulating (increasing blood amount) in blood vessel on certain area. This increasing blood is caused by the blocked vessels as the reaction of some inflamation.

The result of ANOVA analysis suggested that KBE has a significantly influencing congestion damage on infected Common carp fish liver. This is because the antibacteria substances on ketapang tree bark such as fenol and other substances that proved its ability to obstruct $A$. hydrophila development in Common carp fish (C. carpio) liver. Phenol substance and its derivatives, flavonoid are one of antibacteria that work by disturbing the function of the cytoplasms membrane (Volk dan Wheeler, 1984). On the low concentration, it can destroy the cytoplasms membrane, leaking some important metabolite as the bacteria enzyme system activator, while on the higher concentration it can make some damages on cytoplasms membrant and settles the cells' protein.

\section{Melanomacrofag}

Different average results towards melanomacrofag damages occured on Common carp fish (C. carpio). The result showed melanomacrofag on liver with different scoring value average (Figure 3 ). The data from liver damage with the treatment outcome $(A=730 \mathrm{ppm})$ 1.89, ( $B=750 \mathrm{ppm}) 1.56$ dan $(\mathrm{C}=770 \mathrm{ppm})$ 1.33. The ANOVA test indicated that $\mathrm{KBE}$ was not significantly affecting melanomacrofag on Common carp fish liver histopathology.

Liver alteration found in form of melanomacrofag. Melanomakrofag is a type of makrofag that has a lot of melanin pigments inside its cytoplasms. Melanomakrofag formed dense and round shape that has various numbers of pigment and usually found in healthy fish. However, the pigment numbers will increase when fish is depressed. Melanomakrofag is an indicator of chronical stress (Noga, 2010).

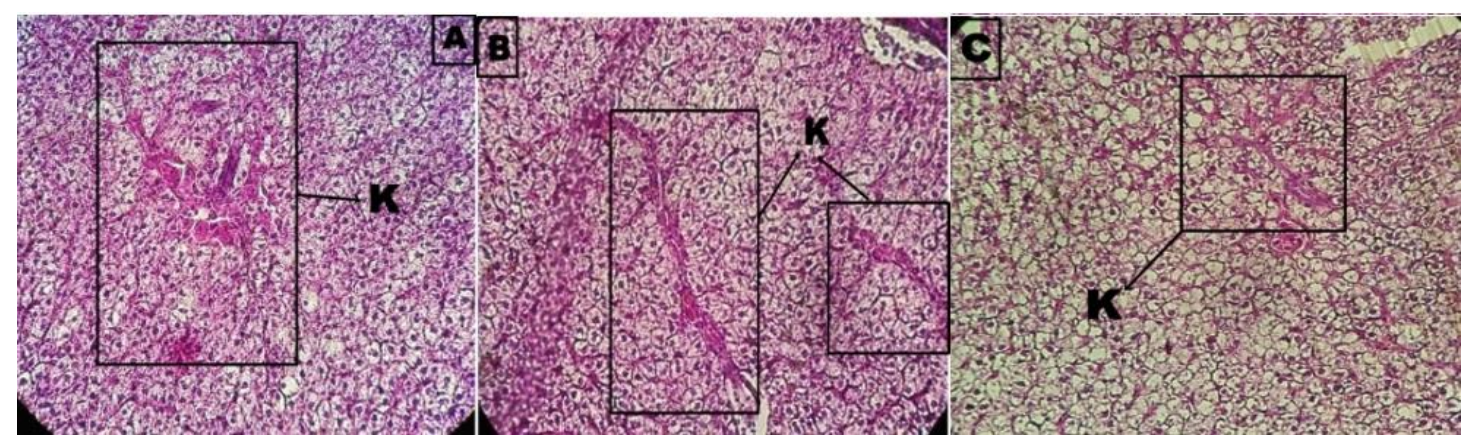

Figure 2. Common carp (Cyprinus carpio) liver tissue that experiencing (K) Congestion; (A) Treatment A (730 ppm); (B) Treatment B (750 ppm); and (C) Treatment C (770 ppm). Observation uses Binocular Microscope, zoomed 400x.

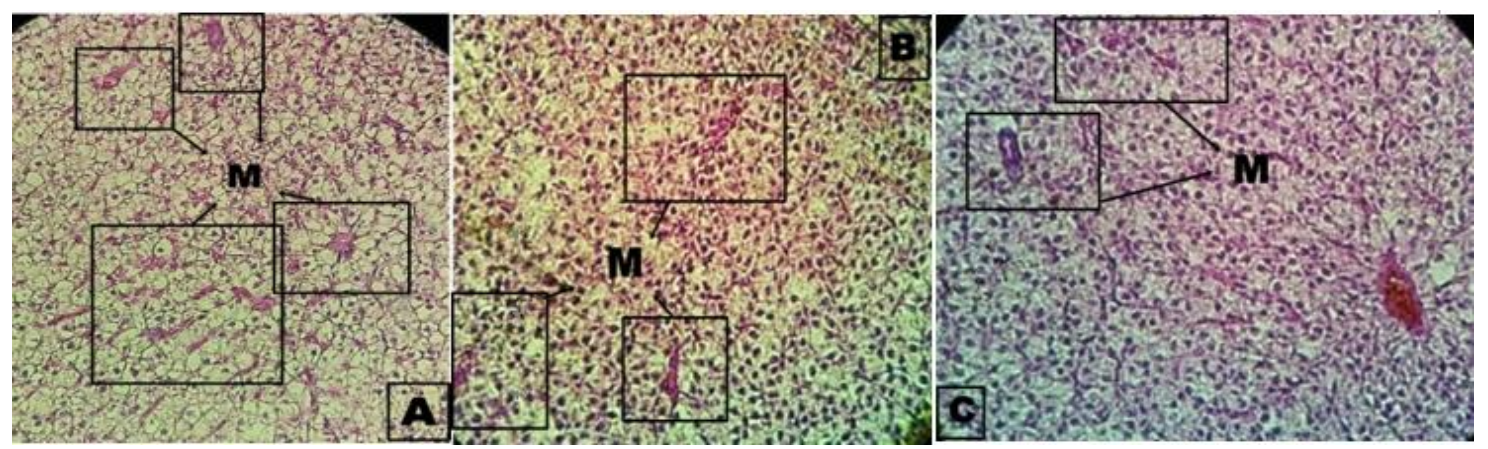

Figure 3. Common carp liver tissue (Cyprinus carpio) with (M) Melanomacrofag (A) Treatment A (730 ppm), (B) Treatment B (750 ppm) and (C) Treatment C (770 ppm). Observation uses Binocular Microscope, 400x zoom. 


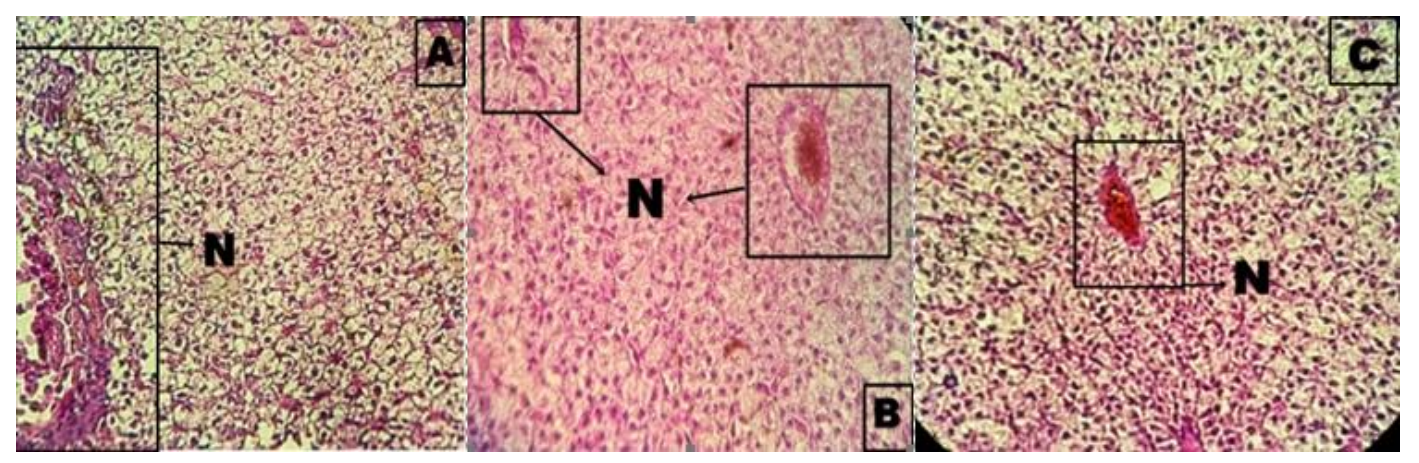

Figure 4. Common carp liver tissue (Cyprinus carpio) with $(N)$ Necrosis $(A)$ Treatment $A$ (730 ppm), (B) Treatment B (750 ppm) and (C) Treament C (770 ppm). Observation uses Binocular Microscope, 400x zoom

\section{Necrosis}

The observation indicated that the liver experienced necrosis (Figure 4.). Ersa (2008) stated that necrosis on fish liver can be resulted from biological warfares (viruses, bacteria, fungus and paracites), or the occurence of damages towards blood supply on some particular area. Liquefactive Necrosis is a necrosis commonly exists on fish where the enzymes inside the cells on fish epithelium or muscle cells that the tissue experiencing necrosis will exfoliated. The treatment gave different average result of necrosis on the fish liver tissue. ANOVA analysis indicated that the treatments are significantly affecting necrosis damages on Common carp fish liver.

Ketapang tree bark contains antibacteria substances such as phenol and flavonoid, saponin and tanin. Tannin as an antibacteria works by agglutinating bacteria cytoplasm cells then it disrupt its metabolism. After that, the work is continued by the active substance called saponin which gives entries to toxic material into the bacteria cells or in another words it leaked the cytoplasm cells that were agglutinated by tannin previously (Alabi et al. (2012). Therefore, the more active ingridients from ketapang tree ( $T$. catappa) bark extract can reduce and obstruct necrosis effects cause by $A$. hydrophila bacterium.

\section{Clinical symptoms}

Clinical symptoms which occur during maintenance period are started with abnormal swimming movement on Common carp fish, such as random and quick swimming movement, sometimes slow and weak and fish often gathered near air source. While from fish physical occured some red marks on fish skin that secreting blood. Also abnormal swollen stomach followed with bruised and blood around it. From the clinical symptomps previously, it can be said that the infection from A.hydrophila bacterium is highly dangerous because it can cause a serious wound and turns into ulcers. Salikin et al. (2014) stated, the symptoms of $A$. hydrophila infected fish are swimming abnormality, pale gill, swollen stomach, and wound/ulcer on skin. The ulcer is surrounded by tissue redness and occured in several part on the whole fish body.

\section{Survival rates (SR) of common carp (C. carpio)}

The result of survival rate of Common carp by using Ketapang bark extract treatment was significantly affecting the SR (Table 1.). The SR for each treatment are $(A=730 \mathrm{ppm})$ $57 \%$; $(B=750$ ppm) 52\%; (C= 770 ppm) $43 \%$ and normal control $90 \%$.

Tabel 2. The survival rate of common carp on the ketapang bark extract.

\begin{tabular}{lcc}
\hline Treatment & Ketapang bark extract $(\mathbf{p p m})$ & Survival rate $(\%)$ \\
\hline A & 730 & 57 \\
B & 750 & 52 \\
C & 770 & 48 \\
\hline
\end{tabular}


The higher concentration of the extract give, then the lower the survival rates value from Common carp fish (C.carpio). The natural contents on extract like tannins in ketapang tree bark will be toxic if the content is high in the medium. Compatible with the statement from Ajizah (2004), tannine that excessively enters the body has a characteristic to shrink intestines that it can disturb peristaltic movement or the movement of intestines muscles. Therefore, it will reduce the appetite and caused death.

\section{Conclusion}

Ketapang ( $T$. catappa) bark extract affects the survival rates and histipathology of Common carp fish (C. carpio) that has been proved through liver damage in forms of congestion and necrosis. The effective dose to reduce damage caused by $A$. hydrophila infection is $770 \mathrm{ppm}$. testing The survival rate of Common carp fish will decrease following the higher concentration of $\mathrm{KBE}$. It is clear that $\mathrm{KBE}$ able to maintain the liver of Common carp however in some extend it will triggering the mortality of Common carp fish. Hence, dose of KBE should be carefully considered.

\section{References}

Ajizah, A. 2004. Salmonella typhimurium sensitivity on Psidium Guajava L. leaves extract. Bioscientie. 1(1): 31-38. (in Indonesian)

Alabi, O. A., Haruna, M.T., Anokwuru, C.P., Jagede, T., Abia, H., Okegbe, V.E., Esan, B.E. 2012. Comperative Studies on Antimicrobial Properties of Extracts of Fresh and Dried Leaves of Carica papaya L. on Clinical Bacterial and Fungi Isolates. Advances in Applied Science Research 3(5): 3107-3114.

Ersa, E.M. 2008. Histopathology of gill, intestine and muscle of Nile (Oreochromis mossambicus) fish in Ciampea, Bogor. Minor thesis. Bogor Agriculture Institute. Bogor. (in Indonesian)

Kordi, M. G. 2004. Eradication of Parasites and Diseases. PT Rineka Cipta and PT Bina Adiaksara. Jakarta. 194 pp..

Noga, E.J. 2010. Fish Disease Diagnosis and Treatment. lowa State University Press. A Blackwell Publishing Company. 54 pp.
Salikin, R. Q., Sarjito., Prayitno, S.B. 2014. Influence of Bihanong (Anhedera cordifolia) leaves extract on mortality and liver histology of Common carp (Cyprinus carpio) which infected by using Aeromonas carviae. Jurnal of Aquaculture Management and Technology. 3(3): 43-50. (in Indonesia )

Sumino, A., Supriyadi., Wardiyanto. 2013. Effectively of Ketapang (Terminalian cattapa L.) leaves extract for treating Aeromonas salmonicida infection on Catfish (Pangasionodon hypopthalamus). Jurnal Sain Veteriner. 31 (1): 79-88. (in Indonesian)

Tabbu, C. R. 2000. Chicken disease. Vol. 1. Kanisius. Yogyakarta. 406 pp.

Volk, W. A., Wheeler, M.F. 1984. Basic Microbiology. Erlangga. Jakarta. 343 pp.

Wahjuningrum, D. N., Ashry., Nuryati, S. 2008. Ketapang (Terminallia cattapa) for treating Aeromonas hydrophila infectedCatfish (Pangasionodion hypopthalamus). Jurnal Akuakultur Indonesia. 7(1): 79-94. (in Indonesian). 